\title{
Farmers' Perceptions of the Effect of Rural Transportation Systems on Farming Income in Ondo State, Nigeria
}

\section{Oluwatoyin Olagunju ${ }^{1 *}$ and Luqman Abiodun Akinbile ${ }^{2}$}

${ }^{1}$ Department of Agricultural Economics and Extension, Adekunle Ajasin University, Akungba-Akoko, Ondo State, Nigeria; ${ }^{2}$ Department of Agricultural Extension and Rural Development, University of Ibadan, Ibadan, Oyo State, Nigeria.

\begin{abstract}
Rural roads are crucial to the socio-economic development of the rural population. Nonetheless, in Nigeria, the state of rural roads is pitiable, as the development, enhancement and provision of more rural transport systems could be a panacea for the prolonged deplorable and worsening state of rural roads in the country. This study examined the perceived effects of rural transportation systems on farmers' income in Ondo State, Nigeria. A structured interview was used in eliciting information from 120 farmers in rural communities across the two local governments in the study area using a two-stage random sampling technique. Data used for the study were analyzed using descriptive statistics and inferential statistics such as chi-square and Pearson Product Moment Correlation (PPMC). The study revealed that farmers perceived the quality of transportation system causes a reduction in their income. Gender $\left(\chi^{2}=6.472\right)$ and marital status $\left(\chi^{2}=9.745\right)$ positively influenced income generated by farmers at $\mathrm{p}<0.05$. Also, there was a significant relationship between transportation systems used $(r=0.705, \mathrm{p}<0.05)$, perceived effects of rural transportation $(r=0.267, p<0.05)$, and income generated by the farmers on farming activities. Based on the results of the study, it could be inferred that improved transport systems would enable farmers to work harder to increase productivity and reduce poverty in rural areas. The study recommended the development of motorable roads with sufficient infrastructure and the establishment of an agency or board capable of monitoring rural infrastructure, in particular, transport infrastructure to promote easy movement and improve the provision of medical services in the area.

Received | December 29, 2019; Accepted | August 06, 2020; Published | Septembe 12, 2020

*Correspondence | Oluwatoyin Olagunju, Department of Agricultural Economics and Extension, Adekunle Ajasin University, Akungba-Akoko, Ondo State, Nigeria; Email: toyinolagunju01@gmail.com

Citation | Olagunju, O. and L.A. Akinbile. 2020. Farmers' perceptions of the effect of rural transportation systems on farming income in Ondo State, Nigeria. Sarhad Journal of Agriculture, 36(3): 985-994.

DOI | http://dx.doi.org/10.17582/journal.sja/2020/36.3.985.994

Keywords | Farmers, Income, Perception, Rural areas, Rural transport systems
\end{abstract}

\section{Introduction}

$\mathrm{R}$ oads in the rural areas are important to rural communities' social, economic and political growth in Nigeria. Such roads allow connection to, among others, market places, educational institutions, health facilities, farms, and other rural areas. Normally, poor roads have unwanted effects not only on produce from agricultural activities but also on the social and economic status of rural dwellers, as economy of the rural areas depends largely on the farmer (Ikejiofor and Ali, 2014). Omollo (2015) and Mathew (2014) pointed that lack of access in rural communities also slows the spread of new techniques and practices, raises the cost of production and marketing distribution, reduces communication levels and restraints access to school attendance and medical care. It also restricts flexibility and makes alienation worse (Nduati, 2017). 
Studies by Hine et al. (2019) also used various indices to track the effect of poor rural roads on the rural economy.

For the socio-economic transformation of rural areas, rural roads are very important. They provide links between rural areas and urban centers and promote the movement of goods, people and services between rural communities and other villages (Ndabeni, 2016). The condition of rural roads in many developing countries, especially Nigeria, is very pitiful despite the contribution of rural roads to the rural economy (Nwankwo and Okeke, 2017). Tunde and Adeniyi (2012) noted that where roads are impassable, transport costs are high and there is confusion about marketing, success in agriculture and rural development will be reduced. Consequently, suitable and reliable rural roads enhance rural productivity, improve physical access, reduce the vulnerability of low income people to uncertainties and anxiety, and help to build ones livelihood assets (Hine et al., 2019).

Different empirical studies have demonstrated the central role of rural roads in the rural economy's socio-economic development. In Bangladesh, Spey et al. (2019) found that rural road development was linked to a $33 \%$ increase in household income and a $24 \%$ increase in agricultural production. Additionally, rural roads facilitate access to educational services by enhanced enrolment levels and better school participation (Starkey and Hine, 2014). For example, in Bhutan, Adukia et al. (2020) found that enrolment of girls in primary schools was three times higher in connected villages than in unconnected villages. Female literacy levels in villages with all seasons of road access in Andhra Pradesh, India are 60 percent higher than those with poor access (Motkuri, 2013).

Likewise, safe access to health services (clinics and hospitals) directly contributes to human capital, which is very critical for sustainable rural development (Akpomuvie, 2010). Hine et al. (2019) revealed that improvements in feeder roads in the Darfur region of Sudan increased the flow of medicinal products into the area, with health centers becoming busier and more efficient, with child immunization increasing by $70 \%$. Whereas in Koga Village, which is still inaccessible child immunization had an appalling $13 \%$ success rate. Not only are rural roads important for agriculture, health and education, they are also very important for marketing purposes (Neubert,
2016). Gebre and Gebremedhin (2019) noted that availability of good rural access is necessary if nonagricultural activities are to break away from and direct their marketing to the outside world. Similarly, Oviasu et al. (2015) found in a research of rural businesses in selected communities in China that a vast majority of business organizations sold over two thirds of their production beyond their province due to presence of good roads.

In other words, the distance between the farm location and the market results in reduced income for the farmer (Migose et al., 2018). Remote farms would also adversely affect the farmer's access to family work by increasing the level of competition between children's schooling and farm work. In some cases, children may have to stop going to school to help out on the farm, or they may have to go to school while farmers have to resort to expensive hired labour (Garner et al., 2014). In developed countries, road network construction in rural communities is not taken into consideration, including Nigeria. This is because either it is taken as a matter of course or its direct and indirect consequences are difficult to quantify (Abur et al., 2015).

For many years, Ondo State's government has placed special focus on constructing, repairing and rehabilitating major roads across different cities within the state to the complete abandonment of rural roads (Adedeji et al., 2014). The rural road networks should be seen as part of the entire public transport system, as they are a significant component in the survival and prosperity of people living in rural areas which require maximum attention as compare to other category of roads (Ayo-Odifiri et al., 2017). The quality of almost all the available land or laterite roads in remote communities is quite perplexing, particularly in the wet season which made it very difficult to pass through (Ayo-Odifiri et al., 2017; Olorunfemi, 2018). Poor roads, besides negative impacts on travelers, farm products and congestion, often result in substantial losses of consumable farm produce, high cost of transporting farm produce and several items, and rising vehicular maintenance expenses (Babatunde et al., 2014; Abur et al., 2015; Oladosu et al., 2018). All of these culminate in high transport costs that adversely affect farmers " incomes.

The two selected local governments have a large 
potential for agricultural resources and are one of the main food baskets in the state. This study will give the researcher the opportunity to obtain first-hand information on the income structure of these rural farmers. The study area is also characterized by some relative problems typical of the rural situation in Nigeria. The rural farmers here face the problems of income generation and access to finance, land policy issues, transport problems and a host of others. The income of farmers in this study is used as a key tool for the isolation of the essential factors that should be given priority in the subsequent rural development policy. This will also lead to the implementation of government efforts to improve rural production visà-vis the generation of rural income in the State in general. It is against this context that the study was carried out to examine farmers' perception of the impact of rural transport systems on their income in Ondo State, Nigeria. The study objectives are to:

1. describe the socio-economic characteristics of the respondents.

2. identify the means of transportation systems available and commonly used in the study area

3. examine the respondents perceived effects of rural transportation systems on their income.

4. determine the relationship between transportation systems used, perceived effects of rural transportation system and the income realized.

\section{Hypotheses}

- There is no significant relationship between selected socio-economic characteristics of farmers and the income generated.

- There is no significant relationship between the perceived effects of rural transportation and farmers' income.

- There is no significant relationship between transportation systems used and the income realized.

\section{Materials and Methods}

\section{Study area}

The study was conducted in Ondo State, specifically in Idanre and Akure South Local Government Areas. Idanre is bounded by longitude $5^{\circ} 00^{\prime} \mathrm{E}$ to $5^{\circ} 15^{\prime} \mathrm{E}$ and latitudes $7^{\circ} 00^{\prime} \mathrm{N}$ to $7^{\circ} 15^{\prime} \mathrm{N}$, covering an area of $750 \mathrm{~km} 2$ and 129,795 inhabitants $(2006$ population census). Idanre's current mountain remains at an altitude of 286-500. It's also elevated in relative to a rainforest zone of Western Nigeria, where temperatures were reported to be around 24$34^{\circ} \mathrm{C}$ with up to $2000 \mathrm{~mm}$ of precipitation. Akure lies north of the equator at $7^{\circ} 25^{\prime}$ and east of the meridian about $5^{\circ} 19^{\prime}$. It's about $700 \mathrm{~km}$ southwest of Abuja and $311 \mathrm{~km}$ north of the State of Lagos (Adeoye, 2016). The two towns are located within Nigeria's tropical rainforest region and they are distinguished by two seasons of climate, the raining and the dry. The raining season runs from March to November, while the dry season begins in late November to early March. Oranges and plantain thrives in Idanre while plantain, cassava etc are cultivated in Akure. The people in these areas are predominantly farmers and cocoa is the main cash crop that is grown in the two local government areas. Also, other crops cultivated include yam, cocoyam, maize, and other food crops. Some people in these areas engage in vulcanizing, tailoring, carpentry, bricklaying, petty trading and lumbering. The vegetation is an evergreen forest with commercial trees all over the places.

\section{Study population}

The research population comprises of arable crop farmers in Ondo State, specifically in Idanre and Akure South Local Government Areas.

\section{Sampling procedure and sample size}

The research implemented a two-stage random sampling method. In the first phase, twenty percent of the total numbers of the communities were randomly selected to give 5 communities from each Local Government. The second phase involves the random sample of 12 respondents in each of the five selected communities with transport systems used. In all, 120 farmers were sampled in the local government areas.

\section{Data collection and analysis}

Data collection was conducted using primary and secondary sources. The primary information was gathered by using an interview schedule made up of well-structured open and close-ended questions, while secondary data were collected from available literature. To test the stated hypotheses, the data were analyzed using descriptive and inferential statistics like Chi-Square and Correlation analysis. The socio-economic characteristics of the respondents were presented using frequency counts, percentages and means. A five-point Likert scale was used to elicit information on the perceived effects of rural transportation systems on income of the respondents. 


\section{Socio-economic characteristics of respondents}

The average age of farmers in Ondo State according to Table 1 indicates 54 years, with the majority $(80.8 \%)$ between 40 and 60 years of age and above. Only $5 \%$ and $14.2 \%$ of them were under and over 30 years of age respectively. This implies that the increasing numbers of older farmers still discovered in agriculture strengthen the reason for the research and according to Fasina (2013); this is not a good sign of enhanced efficiency because farm production is considered to decline as they age, which could negatively affect market involvement and reduce their level of income. The majority $(79.2 \%)$ of the farmers were male while only $20.8 \%$ of them were female. This result indicates a higher percentage of males compared to females, reflecting the fact that the study area has more male-dominated labour force in terms of crop production, which is different from what can be obtained in Sub-Saharan Africa, where about $50 \%$ of females dominated the active labour force $(\mathrm{FAO}, 2011)$. A low percentage of female farmers may be due to their limited access to resources and limited decision-making power compared to their male counterparts (PionceGutierrez, 2016).

Likewise, the findings showed that over half of the respondents were married (68.3\%), $0.8 \%$ were single. While $14.2 \%$ are widowed and $11.7 \%$ separated. More than half $52.5 \%$ of farmers have primary education, with 30\% having secondary education and $15 \%$ having no formal education as shown in Table 1 . This means that the vast majority of farmers in these areas lack enrolment in schools due to unconnected roads in the community. Mukherjee (2012) found in India that the improved access to the school by better roads was three times as high in road connected villages compared to unconnected ones. Table 1 further shows the average income of farmer within a farming season was $\$ 106,015$ (\$294.5). The majority (92.4\%) of them earn between $\$ 70,000$ and $\mathrm{N} 209,000$ (\$194.4 and \$581) per farming season. This implies a substantial percentage of farmers' revenue had allocated to transportation due to bad roads in these areas. This result is consistent with Tunde and Adeniyi (2012); Fungo and Krygsman (2017); they discovered that poor road circumstances impact the transport costs of farm produce that further, affect rural farmers' income.
In addition, the study found that the average year of farmers' experience was 31.50 years. The majority $(81.7 \%)$ of them had between 20 and 40 years of experience. This indicates the large percentage of farmers sampled possessed sufficient agricultural knowledge and experience that will help them to cope with the effect of transportation very well.

The mean household size of the farmers was 8.0, with more than half of them having between 6-10 household sizes. Also, a good number (42\%) of farmers transport their farm produce using vehicles, while $37 \%$ and $18 \%$ used foot and motorcycle accordingly. This means about $50 \%$ of respondents utilized vehicles to transport their farm produce more than any other means of transportation in the area. It also indicated that they spent more money on both motorcycles and vehicle every month. This research is consistent with studies of Tunde and Adeniyi, 2012; Rabirou et al., 2012; Olagunju et al., 2012; Yaro et al., 2014; Kiprono and Matsumoto, 2014; Abur et al., 2015; Kiprono and Matsumoto, 2018, which emphasized that farmers used vehicles more than any other means of transportation to transport their farm produce and this goes a long way to affect their income negatively.

On the cost of transportation incurred by the respondent per month, the majority (98.3\%) spent between $\$ 100$ and $\$ 3900$ (\$0.3 and \$11) using a motorcycle, while $63 \%$ of them spent more than N3600 (\$10) using vehicles depending on the distance. This implies a substantial percentage of farmers' revenue had allocated to transportation due to bad roads in these areas. This finding was consistent with Ogunleye et al. (2018) as they confirmed that if transport costs were reduced, rural demand would be stimulated and increase rural income as a result of good roads. Road quality has led to significant response to production and revenue, with a $10 \%$ significant change in state of the roads resulting in a $12 \%$ increase in crop production output and a $2.2 \%$ increase in overall household income. Finally, Table 1 revealed $70.0 \%$ of farmers are Christians while 25\% are Muslims. Hence, Idanre and Akure local government areas are predominantly Christian communities this is manifested in the existence of several churches in the areas. This implies that many Christians are involved in the transportation of agricultural produce. 
Table 1: Distribution of respondents based on their selected personal characteristics.

\section{Selected personal characteristics}

Age

20-29

30-39

40-49

50-59

60 and above

Gender

Male

Female

Educational status

$\begin{array}{lll}\text { No formal education } & 18 & 15 \\ \text { Primary education } & 63 & 52.5 \\ \text { Secondary education } & 36 & 30 \\ \text { Tertiary education } & 3 & 2.5\end{array}$

Household

$\begin{array}{llll}1-5 & 44 & 36.7 & \text { Mean= } \\ 6-10 & 69 & 57.5 & 8.0 \\ 11 \text { and above } & 7 & 5.8 & \end{array}$

Marital status

$\begin{array}{lll}\text { Single } & 1 & 0.8 \\ \text { Married } & 82 & 68.3 \\ \text { Divorced } & 6 & 5.0 \\ \text { Widowed } & 17 & 14.2 \\ \text { Separated } & 14 & 11.7 \\ \text { Religion } & & \\ \text { Christian } & 84 & 70.0 \\ \text { Islam } & 30 & 25.0 \\ \text { Traditionalist } & 6 & 5.0\end{array}$

Years of experience

$\begin{array}{llll}1-19 & 16 & 18.3 & 31.50 \\ 20-39 & 86 & 69.1 & \\ 40 \text { and above } & 13 & 12.6 & \end{array}$

Transportation systems used

$\begin{array}{lll}\text { By foot } & 45 & 37 \\ \text { By bicycle } & 4 & 3 \\ \text { By motorcycle } & 21 & 18 \\ \text { By vehicle } & 50 & 42\end{array}$

Cost of transportation per month $(\mathrm{N} / \mathrm{\$})$

By motorcycle

$\begin{array}{lll}100-1900(0.3-5.2) & 83 & 69.1 \\ 2000-3900(6-10.8) & 35 & 29.2 \\ 4000(11.1) \text { and above } & 2 & 1.7\end{array}$

By vehicle

600-1500 (2-4.1)
Selected personal characteristics

$\begin{array}{lll}1600-2500(4.4-7) & 27 & 22.5 \\ 2600-3500(7.2-9.7) & 15 & 12.5 \\ 3600(10) \text { and above } & 63 & 52.5\end{array}$

Income realized (N/\$)

10,000-69,000 (27.7-192) 16

3.5

Mean=

70,000-139,000 (194.4- $\quad 86$

386.1)

61.7

106,015

140,000-209,000 (389-581) 13

30.7

$210,000(583.3)$ and above 5
$(\$ 294.4)$

Source: Field survey, 2018. Naira to US dollar conversion rate: $\$ 360$ to $\$ 1$ US dollar.

Table 2 indicates how the respondents are distributed according to their perceived effects of rural transportation systems on farmers' income. Farmers perceived the quality of transportation system causes vehicle not to be available (mean $=5.20$ ), they also felt that the quality of transportation system discourage farmers from selling their crops (mean=5.20). Farmers expressed that the quality of the transportation system leads to the damage of their crops (mean=5.17) and also affects their health status (mean=5.14). The table further shows that more than half $(67.5 \%)$ of the farmers agreed to the fact that the quality of transportation network causes a reduction in their income (mean=5.13), while $62.5 \%$ indicated the quality of transportation system causes an increase in transport fares (mean=5.12). The inference is that farmers'view of transport systems presents significant problems by hindering their smooth marketing system and income. The result is consistent with Barrett et al. (2017), indicating that inadequate transportation and communications infrastructure presents significant challenges by preventing the proper functioning of the market for farmers trying to purchase inputs or sell farm produce as well as for post-harvest processing and this could negatively affect market involvement and reduce their level of income.

\section{Hypotheses testing}

The results presented in Table 3 clearly reveals that there had been no significant association between religion $\left(\chi^{2}=2.524, p>0.05\right)$, educational status $\left(\chi^{2}=4.753\right.$, $\mathrm{p}>0.05)$ and revenue earned by the farmer. However, their gender $\left(\chi^{2}=6.472, p<0.05\right)$ and marital status $\left(\chi^{2}=9.745, p<0.05\right)$ had a significant relationship with income generated by farmers. This result implies that the farmers' income generated is irrespective of their 
Table 2: Frequency distribution of perceived effects of rural transportation systems on farmer's income.
S/n Statement

\section{Strongly Agree} agree
1 The quality of transportation system causes vehicles not to be 34 (28.3) available
2 The quality of transportation system leads to the damage of crops
3 The quality of transportation system causes a reduction in farmers' income
4 The quality of transportation system causes an increase in transport fares
5 The quality of transportation system affects my health status $1(0.8)$
$32(26.7) \quad 82(68.3) \quad 1(0.8)$ $\begin{array}{ll}\text { Undecid- Disagree } & \begin{array}{l}\text { Strongly } \\ \text { disagree }\end{array}\end{array}$
$82(68.3) \quad 3(2.5)$
$1(0.8) \quad 5.20$
6 The quality of transportation system discourages farmers from 2 (1.7) selling their crops
7 The quality of transportation system encourages the selling of - crops.
8 The present condition of the roads makes transportation of crops to the market easier
9 The quality of the transportation system causes a delay in transporting crops to the market
10 The quality of transportation system enhance rotting of crops 2 (1.7)
$1(0.8)$
$75(62.5) \quad 40(33.3) \quad 3(2.5)$
$2(1.7)$

$\begin{array}{lllll}40(33.3) & 52(43.3) & 21(17.5) & 6(5.0) & 5.14 \\ 89(74.2) & 9(7.5) & 15(12.5) & 5(4.2) & 5.20\end{array}$
$50(41.7) \quad 69(57.5) \quad 4.97$
$1(0.8) \quad 7(5.8)$
$14(11.7) \quad 98(81.7) \quad 2.48$
$13(10.8) \quad 88(73.3) \quad 6(5.0)$
$10(8.3) \quad 3(2.5) \quad 5.01$
$70(58.3) \quad 15(12.5)$
$21(17.5) \quad 12(10.0) \quad 4.99$

Source: Field survey, 2018.

religion and educational status, but on their gender and marital status. The significance of marital status is due to the age category in which, due to advancing age, they have gained experience over time. The predicted relationship between gender and income has been established; meaning that women are more involved in the marketing and processing of farm produce than men in African countries such as Nigeria, particularly in vegetable cultivation and agricultural product marketing (Odebode, 2012). In a related study, Ayanwuyi et al. (2015) reiterated the role of gender in the income of farmers and the marketing of agricultural products.

Table 3: Chi-Square analysis of the relationship between selected personal characteristics and the income generated.

\begin{tabular}{lllllll}
$\begin{array}{l}\text { Selected personal } \\
\text { characteristics }\end{array}$ & $\boldsymbol{x}^{2}$ & \multicolumn{3}{l}{ df $\mathbf{c c}$} & \multicolumn{2}{c}{ p-value decision } \\
Gender & 6.472 & 1 & 0.301 & $0.011^{*}$ & Significant \\
Marital status & 9.745 & 4 & 0.361 & $0.045^{*}$ & Significant \\
Religion & 2.524 & 2 & 0.193 & 0.283 & Not Significant \\
Educational status & 4.753 & 3 & 0.261 & 0.191 & Not Significant
\end{tabular}

"significant: $p<0.05 ; x^{2}$ : Chi-square value; $d f$ : degree of freedom; cc: contingency coefficient; $p$-value: asymptotic significance value.

The results obtained in Table 4 found that a significant relationship existed between the transports system used $(r=0.705, \mathrm{p}<0.05)$ by the farmers and income generated on farming activities. The analysis shows that improved transport will allow farmers to work more effectively in rural areas to increase agricultural output, bring value to products and services, minimize the amount of waste and post-harvest losses, empower farmers and provide a significant influence on the local production, earnings and reducing poverty. The result is in consonance with the findings of Owagbemi (2018) and Usman (2014) as they reported that transport occupies important position production and distribution of food structure, and that easy movement to the market can help a lot in the level of rural income. The Table further revealed a significant relationship existed between the perceived effects of rural transport used $(r=0.267, p<0.05)$ by the farmers and income generated on farming activities. It means that the farmers' transportation has an effect on their profits. Farmers use difference kinds of marketing mediums to market their products and each marketing channel has associated costs such as transportation costs, produce profits and prices. In a related study, Akangbe et al. (2013), Lawal et al. (2016), Yeboah (2016) and Claudia (2017) found that high transportation costs would discourage farmers from participating in local markets from selling their livestock and other farm produce, focusing instead on farm gate sales, which would limit their incomegenerating opportunities. 
Table 4: Pearson Product Moment Correlation (PPMC) showing relationship between transportation systems used, perceived effects of rural transportation system and the income realized.

$\begin{array}{lllll}\text { Variables } & \text { r-value } & \text { p-value Decision } & \text { Remark } \\ \begin{array}{l}\text { Transportation } \\ \text { systems used }\end{array} & 0.705 & 0.000^{*} & \text { Significant } & \mathrm{H}_{0} \text { rejected } \\ \text { Perceived } & & & & \end{array}$

Perceived effects of $0.267 \quad 0.003^{*}$ Significant $\mathrm{H}_{0}$ rejected rural transportation

*Significant: $p<0.05$

\section{Conclusions and Recommendations}

This study could be inferred that the nature of transportation systems available in these communities has a significant impact on the level of income to be realized by farmers. Based on the above findings, we can always draw the conclusion that enhanced road network will motivate farmers to strive extremely hard to boost agricultural production, create value to products and services, minimize decay of farm produce and avoid wastage, strengthen farmers and even have a beneficial effect on farming performance, income, employment and alleviate poverty in rural and remote areas of developing countries. Moreover, the result has shown that the serious constraints faced by the farmers' such as the high cost of transport due to the quality of transport systems have a great influence on the income generated by the farmers.

The following recommendations are made, based on the findings of the study;

- To ensure a sustainable transport network, transport policy should be in place at local, state, and federal level. Such a policy should underpin the already existing relationship between the transport network and the development of socio-economic activities, while at the same time creating a favourable transport system for further growth.

- The Government should open up new roads in the villages in order to ease the misery of the rural masses.

- Adequate storage facilities should be made available to farmers in rural areas to allow them store and prevent the deterioration of farm produce in the event of a delayed vehicle which, in effect, increases the return of farmers.

- Remote communities, such as agricultural settlements in and around Ondo State, should be linked by good roads in order to improve connectivity and mobility to these areas as this will increase the use of local resources.

- Network roads connecting the market should be rehabilitated for easy transport, which may ultimately reduce the high cost of transport.

- All three levels of government in Nigeria (Federal, State and Local) should try as much as possible to provide pickups to rural areas in order to alleviate their poverty as they also provide mass transit to urban areas.

- The Ondo State Road Maintenance Agency (OSRMA) should identify poorly maintained roads in the state (especially state-controlled roads) and focus on their restoration and put them in good working order rather than road construction. The government should be concerned about the construction of new roads. The extent to which the road network is connected in the state and the construction of these new roads should be managed by professional construction companies that are better equipped financially and otherwise.

\section{Novelty Statement}

The paper emphasizes the importance of road infrastructure on farm produce in rural areas. It contributes to raising farmers' incomes and implementing policies aimed at addressing employment and poverty reduction in rural areas.

\section{Author's Contribution}

The first draft of the manuscript was written, analyzed and written by OO. LAA took part in the review, correction and formatting of the paper. The final manuscript was read and approved by all authors.

\section{Conflict of interest}

The authors have declared no conflict of interest.

\section{References}

Abur, C.C., G.R. Ademoyewa and M. Damkor. 2015. Impact of rural roads infrastructure on the income and productivity of households farmers in North Central Nigeria. Res. J. Agric. Environ. Manage., 4(10): 451-458.

Adedeji, O., E.M. Olafiaji, F.K. Omole,J.A. Olanibi and Y. Lukman. 2014. An assessment of the impact of road transport on rural development: A case study of Obokun local government area 
of Osun State, Nigeria. Br. J. Environ. Sci., 2(1): 34-48.

Adeoye, D.O., 2016. Challenges of Urban Housing Quality: Insights and Experiences of Akure, Nigeria. Proc. Soc. Behav. Sci., 216: 260-268. https://doi.org/10.1016/j.sbspro.2015.12.036

Adukia, A., S. Asher and P. Novosad. 2020. Educational investment responses to economic opportunity: evidence from Indian road construction. Am. Econ. J. Appl. Econ., 12(1): 348-376. https://doi.org/10.1257/ app. 20180036

Akangbe,J.A., O.O.Oloruntoba.B.Achem and S.E. Komolafe. 2013. An appraisal of transportation facilities effects on agricultural development in Moro Local Government Area, Kwara State, Nigeria. Ethiop. J. Environ. Stud. Manage., 6(2): 191-200. https://doi.org/10.4314/ejesm. v6i2.10

Akpomuvie, O.B., 2010. Poverty, access to health care services and human capital development in Nigeria. Afr. Res. Rev., 4(3): 42-55. https://doi. org/10.4314/afrrev.v4i3.60149

Ayanwuyi, E., J.O. Akintonde and A.O. Tiamiyu. 2015. Assessment of perceived corrupt practices in marketing of agricultural produce among women marketers in ogbomoso agricultural of Oyo State, Nigeria. Int. J. Appl. Agric. Apic. Res., 11(1-2): 157-161.

Ayo-Odifiri, O.S., J.O. Fasakin and F.O. Henshaw. 2017. Road connectivity approach to eased traffic congestion on market roads in Benin metropolis, Nigeria. Am. J. Eng. Res., (AJER), 6(6): 41-48.

Babatunde, R.O., A.H. Adenuga, F.I. Olagunju and A.O.Oladoja.2014. Effect of road infrastructure on farm production in Oyo state, Nigeria. Ethiop. J. Environ. Stud. Manage., 7(2): 197201. https://doi.org/10.4314/ejesm.v7i2.11

Barrett, C.B., L. Christiaensen, M. Sheahan and A. Shimeles. 2017. On the structural transformation of rural Africa. The World Bank. https://doi.org/10.1596/1813-9450-7938

Claudia N., Berg, U. Deichmann, Y. Liu and H. Selod.2017.Transport policies and development. J. Dev. Stud., 53(4): 465-480. https://doi.org/10 $.1080 / 00220388.2016 .1199857$

FAO, 2011. The state of food and agriculture 2010-

11. Women in agriculture: Closing the gender gap for development (www.fao.org/docrep/013/ i2050e/ i2050e.pdf).
Fasina, O.O., 2013. Farmer's perception of the effect of aging on their agricultural activities in Ondo state, Nigeria. Venets Belogradchik J. Loc. Hist. Cult. Herit. Folk Stud., 4(3): 371-387.

Fungo, E. and S. Krygsman. 2017. Impact of rural roads conditions on transport price of agricultural products (No.17-03232).

Garner, E., O'Campos de la and A. Paula. 2014. Identifying the "family farm": an informal discussion of the concepts and definitions (ESA Working Paper No 14-10). Italia: Food and Agriculture Organization.

Gebre, T. and B. Gebremedhin. 2019. The mutual benefits of promoting rural-urban interdependence through linked ecosystem services. Glob. Ecol. Conserv., 20:1-14. https:// doi.org/10.1016/j.gecco.2019.e00707

Hine, J., M. Sasidharan, M.E. Torbaghan, M. Burrow and K. Usman. 2019. Evidence of the impact of rural road investment on poverty reduction and economic development.

Ikejiofor, I.G. and A. Ali. 2014. The effects of road transport characteristics on the marketing of agricultural produce in Nsukka Lga, Enugu State, Southeastern Nigeria. Innovare J. Soc. Sci., 2(1): 1-4.

Khapayi, M., and P.R. Celliers. 2016. Factors limiting and preventing emerging farmers to progress to commercial agricultural farming in the King William's Town area of the Eastern Cape Province, South Africa. South Afr. J. Agric. Ext., 44(1): 25-41. https://doi. org/10.17159/2413-3221/2016/v44n1a374

Kiprono, P. and T. Matsumoto. 2014. Roads and farming: The effect of infrastructure improvement on agricultural input use, farm productivity and market participation in Kenya. In: CSAE Conf., pp. 23-25.

Kiprono, P. and T. Matsumoto. 2018. Roads and farming: the effect of infrastructure improvement on agricultural intensification in South-Western Kenya. Agrekon, 57(3-4): 198220. https://doi.org/10.1080/03031853.2018.1 518149

Lawal, A.L., O.D. Olorunfemi, K. Olatinwo and Y. Olatunji. 2016. Perceived effects of poor road transportation network on crop production in Kaiama local government area of Kwara state, North Central Nigeria. Int. J. Agric. Manage. Dev., 6(4): 497-503.

Mathew, B., 2014. Influence of road maintenance 
on economic development of rural areas: A case of moiben constituency, Uasin Gishu County, Kenya. M.A. thesis, Univ. Nairobi, Nairobi, Kenya.

Migose, S.A., B.O. Bebe, I.J.M. de Boer and S.J. Oosting. 2018. Influence of distance to urban markets on smallholder dairy farming systems in Kenya. Trop. Anim. Health Prod., 50(7): 1417-1426. https://doi.org/10.1007/s11250018-1575-x

Motkuri, V., 2013. Education and literacy in Andhra Pradesh (Pre-School, School, Higher and Technical Education and Adult Literacy and Skills).

Mukherjee, M., 2012. Do better roads increase school enrollment? Evidence from a unique road policy in India. Evidence from a Unique Road Policy in India (August 28, 2012). https:// doi.org/10.2139/ssrn.2207761

Ndabeni, L.L., 2016. An analysis of rural-urban linkages and their implications for policies that sustain development in a space continuum. South Africa: Ministry of Cooperative Governance and Traditional Affairs.

Nduati, J.K., 2017. Institutional factors influencing completion of Kenya rural roads authority projects in ruiru sub county, Kenya. M.A. thesis, University of Nairobi, Nairobi, Kenya.

Neubert S., 2016. Rural roads are essential facilitating agriculture development in Africa (www.dandc.eu/en/article/rural-roads-areessential-facilitating-agriculture-developmentafrica).

Nwankwo, F.O. and C.S. Okeke. 2017. Rural entrepreneurship and rural development in Nigeria. Afr. Publ. Ser. Delivery Perform. Rev., 5(1): a152. https://doi.org/10.4102/apsdpr. v5i1.152

Odebode, S.O., 2012. Gender issues in agricultural extension and rural development in Nigeria. Intech Open Access Publisher.

Ogunleye, O., A. Ajibola, O. Enilolobo and O. Shogunle. 2018. Influence of road transport infrastructure on agricultural sector development in Nigeria. Logist. Sustainable Transp., 9(1): 39-50. https://doi.org/10.2478/ jlst-2018-0004

Oladosu J.O., O.J. Kolawole and F.A. Mensah. 2018. The effect of rural transport infrastructure on agricultural productivity in some selected local governments of Oyo State. Int. J. Res.
Humanit. Arts Lit., 6(11): 85-94.

Olagunju, F.I., O.E. Ayinde, M.O. Adewumi and G.B. Adesiji. 2012. Effect of rural roads and marketing infrastructure on income of farming households in Osun state: Implications for sustainable development. World Rural Observ., 4(2): 20-30.

Olorunfemi, S.O., 2018. Rural road transportation challenges and food security in Ikere-Ekiti, Ekiti State, Nigeria. Ethiop. J. Environ. Stud. Manage., 11(5): 553-564.

Omollo, O.G., 2015. Influence of sustainable maintenance of rural roads on socio-economic activities: A case of households of Rongo constituency in Migori County, Kenya. B.Sc. project, University of Nairobi, Nairobi, Kenya.

Oviasu, O., J.E. Rigby and D. Ballas. 2015. Chronic kidney disease in Nigeria: An evaluation of the spatial accessibility to healthcare for

diagnosed cases in Edo State. J. Public Health Afr., 6(394): 40-44. https://doi.org/10.4081/ jphia.2015.394

Owagbemi, G.O., 2018. Assessing the relocation of Adekunle Ajasin University to Akokoland on transportation system and rural development in Ondo State. Humanit. Soc. Sci. Lett., 6(2): 51-58. https://doi.org/10.18488/ journal.73.2018.62.51.58

Pionce-Gutierrez, E.G., 2016. Agricultural performance in northern Ghana: A gender decomposition. M.Sc. thesis, Kansas State University, Manhattan, United States.

Rabirou, K., A.B. Ayanwale, E.O. Idowu and S.B. Williams. 2012. Effect of rural transportation system on agricultural productivity in Oyo State, Nigeria. J. Agric. Rural Dev. Trop. Subtropics (JARTS), 113(1): 13-19.

Spey, I.K., D. Kupsch, K.S. Bobo, M. Waltert and S. Schwarze. 2019. The effects of road access on income generation. evidence from an integrated conservation and development project in Cameroon. Sustainability, 11(3368): 1-14. https://doi.org/10.3390/su11123368

Starkey,P. and J.Hine. 2014.Poverty and sustainable transport: How transport affects poor people with policy implications for poverty reduction. A literature review.

Starkey, P., R. Workman and J. Hine. 2019. Interactions between improved rural access infrastructure and transport services provision: Phase 1 Scoping Report. ReCAP GEN2136A. 
London: ReCAP for DFID.

Tunde, A.M. and E.E. Adeniyi. 2012. Impact of road transport on agricultural development: A Nigerian example. Ethiop. J. Environ. Stud. Manage., 5(3): 232-238. https://doi. org/10.4314/ejesm.v5i3.3

Usman, A.B., 2014. Analysis of condition of rural road transport in Kwara State, Nigeria. Eur. Sci. J., 10(5): 288-307.

Yaro, M.A., A.E. Okon and D.B. Bisong. 2014. The impact of rural transportation on agricultural development in Boki Local Government Area, Southern Nigeria. J. Manage. Sustainability, 4: 125. https://doi.org/10.5539/jms.v4n4p125

Yeboah, S., 2016. Influence of condition of road transport infrastructure on rural agricultural development in the Jaman South District. PhD thesis, Kwame Nkrumah University of Science and Technology, Kumasi, Ghana. 